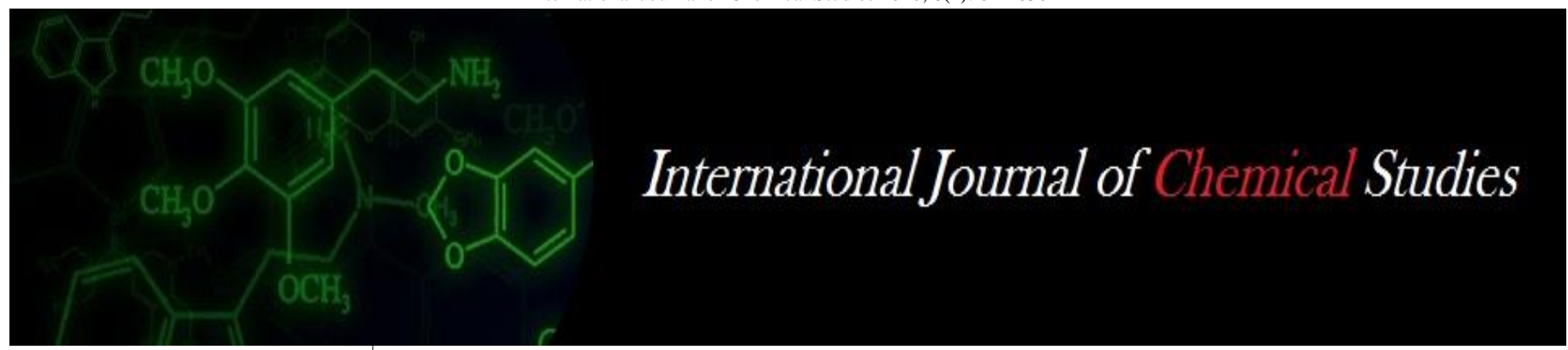

P-ISSN: 2349-8528

E-ISSN: 2321-4902

www.chemijournal.com

IJCS 2020; 8(2): 624-630

(C) 2020 IJCS

Received: 10-01-2020

Accepted: 12-02-2020

Adama Diarrassouba Tuo Centre de Recherches

Océanologiques (CRO), 29, Rue des Pêcheurs, Treichville, BP

V18 Abidjan, Côte d'Ivoire

Metongo Bernard Soro

Centre de Recherches

Océanologiques (CRO), 29, Rue des Pêcheurs, Treichville, BP

V18 Abidjan, Côte d'Ivoire

Albert Trokourey

UFR SSMT, Laboratoire de Chimie Physique, Université Félix Houphouët-Boigny, 22 BP 582 Abidjan 22, Côte d'Ivoire

Yobou Bokra

UFR SSMT, Laboratoire de Chimie Physique, Université Félix Houphouët-Boigny, 22 BP 582 Abidjan 22, Côte d'Ivoire

Corresponding Author: Adama Diarrassouba Tuo Centre de Recherches Océanologiques (CRO), 29, Rue des Pêcheurs, Treichville, BP V18 Abidjan, Côte d'Ivoire

\section{Seasonal variation in trace metal contents in oyster Crassostrea gasar from the Milliardaires Bay, Côte d'Ivoire}

\section{Adama Diarrassouba Tuo, Metongo Bernard Soro, Albert Trokourey and Yobou Bokra}

DOI: https://doi.org/10.22271/chemi.2020.v8.i2j.8838

\begin{abstract}
To assess seasonal variations in trace metals contents in oyster Crassostrea gasar, samples were collected from six selected stations in Milliardaires Bay (Côte d'Ivoire) in the dry, flood and rainy seasons. Lead $(\mathrm{Pb})$, cadmium $(\mathrm{Cd})$, nickel $(\mathrm{Ni})$, manganese $(\mathrm{Mn})$ and zinc $(\mathrm{Zn})$ concentrations were determined in the soft tissues by flame atomic absorption spectroscopy. Average ( \pm standard deviation) concentrations of $\mathrm{Pb}, \mathrm{Cd}, \mathrm{Ni}, \mathrm{Mn}$, and $\mathrm{Zn}$ ranged from $40.06 \pm 124.77$ to $301.91 \pm 216.27,1.44 \pm 0.87$ to $2.29 \pm 1.64,23.86 \pm 18.46$ to $172.32 \pm 518.55,25.96 \pm 19.41$ to $55.00 \pm 63.20$ and $2537.34 \pm 1537.78$ to $3322.99 \pm 2096.71 \mu \mathrm{g} / \mathrm{g}$ dry weight respectively. According to the two-way ANOVA analysis of variance, seasonal variations of $\mathrm{Pb}, \mathrm{Ni}$, and $\mathrm{Zn}$ were statistically significant $(\mathrm{p} \leq 0.0001)$, at the opposite of $\mathrm{Cd}$ $(\mathrm{p}=0.9977)$ and $\mathrm{Mn}(\mathrm{p}=0.7780)$ ones. $\mathrm{Pb}$ exhibited highest contents in the dry season, while those of $\mathrm{Cd}$ and $\mathrm{Zn}$ recorded in the flood and rainy ones. The seasonal variations of $\mathrm{Ni}$ and $\mathrm{Zn}$ were found dependent on the individual location each sampling station. The concentrations of the toxic metals $(\mathrm{Pb}$ and $\mathrm{Cd})$ were of particular concern, calling efforts to address the contamination problem in Milliardaires Bay.
\end{abstract}

Keywords: Bioaccumulation, trace metals, toxicity, oyster, Crassostrea gasar, seasonal variation, Milliardaires Bay, Côte d'Ivoire

\section{Introduction}

Trace metals are among pollutants that can have hazardous effects on marine organisms and human as consumers. If metals leached from soil and rocks to aquatic systems are known to be naturally ubiquitous and pose minimal threats to the environment and human health (PáezOsuna and Osuna-Martínez, 2015) ${ }^{[18]}$, those of several anthropogenic sources (domestic, agriculture, aquaculture, harbor and mining) increase metal burdens exceeding natural levels (Góngora-Gómez et al., 2017) ${ }^{[6]}$. Alterations of enzyme activities such as alkaline phosphatase, abnormal development of fetus, procreation failure, and immunodeficiency are among harmful effects due to aquatic metal exposure (Zhou et al., 2008) ${ }^{[30]}$. Bivalves, as sessile organisms that can accumulate and exhibit efficient strategies to deal with the potential toxic effect of metals (Arifin and Bendell-Young, 1997) ${ }^{[1]}$ and their abundance and wide distribution, they are widely utilized as biomarkers for monitoring metal contamination in aquatic systems (Kanthai et al., 2014) ${ }^{[10]}$. Since oysters are sedentary and filter feeders, they are susceptible to metal accumulation and, therefore, are ideal sentinel organisms for assessing environmental pollution along tropical and subtropical coasts (Páez-Osuna et al., 1995) ${ }^{[16]}$. Further, this bivalve can be a vector of toxic chemicals such as trace metals for humans as its consumers. Since the 1980s, several species of the genus Crassostrea have been studied worldwide in relation to metal contamination such as Crassostrea commercialis in the Gulf of Thailand (Phillips and Muttarasin, 1985) ${ }^{[19]}$, Crassostrea angulata on the Spanish south Atlantic shore (Lopez-Artiguez et al., 1989) ${ }^{[12]}$ and Crassostrea corteziensis on the northwest coast of Mexico (Páez-Osuna and Marmolejo-Rivas, 1990) ${ }^{[17]}$, Crassostrea gasar on a lagoon of Togo (Ouro-Sama et al., 2014) ${ }^{[15]}$, Crassostrea gasar of Côte d'Ivoire (Metongo et al., 1991; Tuo et al., 2019) ${ }^{[13,25]}$. Seasonal variations of metals bioaccumulation in marine organisms are also studied worldwide (Prabal et al., 2011; Weng and Wang, 2019) ${ }^{[20,27]}$. In Côte d'Ivoire, the oyster Crassostrea gasar is widely present in several coastal areas 
(Metongo et al., 1991) [13]. Previous studies conducted in Milliardaires Bay have revealed a seasonal variation in nutrients, metals and organic matter concentrations in waters and sediments (Tuo et al. 2012; Tuo et al., 2013; Bakary et al., 2014; Tuo et al, 2015) ${ }^{[22,23,2,24]}$ and high levels of metals in bivalves such as Anadara senilis with seasonal variations (Bakary et al., 2015) ${ }^{[3]}$ and Crassostrea gasar (Metongo et al., 1991; Tuo et al., 2019) ${ }^{[13]}$ in relation with an increase in anthropogenic activities around the Ebrié Lagoon including the Milliardaires Bay, thus indicating a potential risk for human health. Tuo et al., (2019) ${ }^{[25]}$ have reported high concentrations of $\mathrm{Pb}$ in $C$. gasar inhabiting Milliardaires Bay, with high values of bioconcentration factors (BCF), thus confirming its abilities in metal bioaccumulation. Other studies were conducted to assess population dynamics (Yapi et al., 2017) ${ }^{[28]}$, reproduction cycle (Yapi et al., 2018) ${ }^{[29]}$ and histological study of sex annual cycle of $C$. gasar from Ebrié and Aby Lagoons (Kouakou et al., 2018) ${ }^{[11]}$. If there are a few studies regarding metals concentrations in oysters from

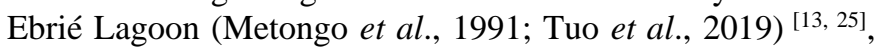
there are no data in relation with the seasonal variations of trace metals contents in the tissues of the oyster Crassostrea gasar inhabiting the Ebrié lagoon. The present paper presents a study on seasonal variation of trace metals $(\mathrm{Pb}, \mathrm{Cd}, \mathrm{Ni}, \mathrm{Mn}$ and $\mathrm{Zn}$ ) concentrations in the soft tissues of the oyster $C$. gasar collected from six locations along the Milliardaires Bay in the dry, rainy and flood seasons.

\section{Materials and Methods}

Study area: Oysters were collected in Milliardaires Bay, located in the Ebrié Lagoon of Côte d'Ivoire (Fig. 1). The Milliardaires Bay $\left(4^{\circ} 19^{\prime}-4^{\circ} 27^{\prime} \mathrm{W} ; 5^{\circ} 8^{\prime}-5^{\circ} 10^{\prime} \mathrm{N}\right)$ is located at approximately $50 \mathrm{~km}$ from Abidjan Harbor (Bakary et al., 2015) ${ }^{[3]}$. The climate is of sub-equatorial with three distinguish lagoon seasons including a Dry Season (December- March), a rainy season (April- August) and a flood season (September-November). These three seasons influence the lagoon chemistry due to nature and levels of waters that dilute the lagoon ones. Indeed, dilution waters are from marine origin in the dry season, while they are of continental origin in the rainy and flood seasons (Tuo et al., 2012) $)^{[22]}$.

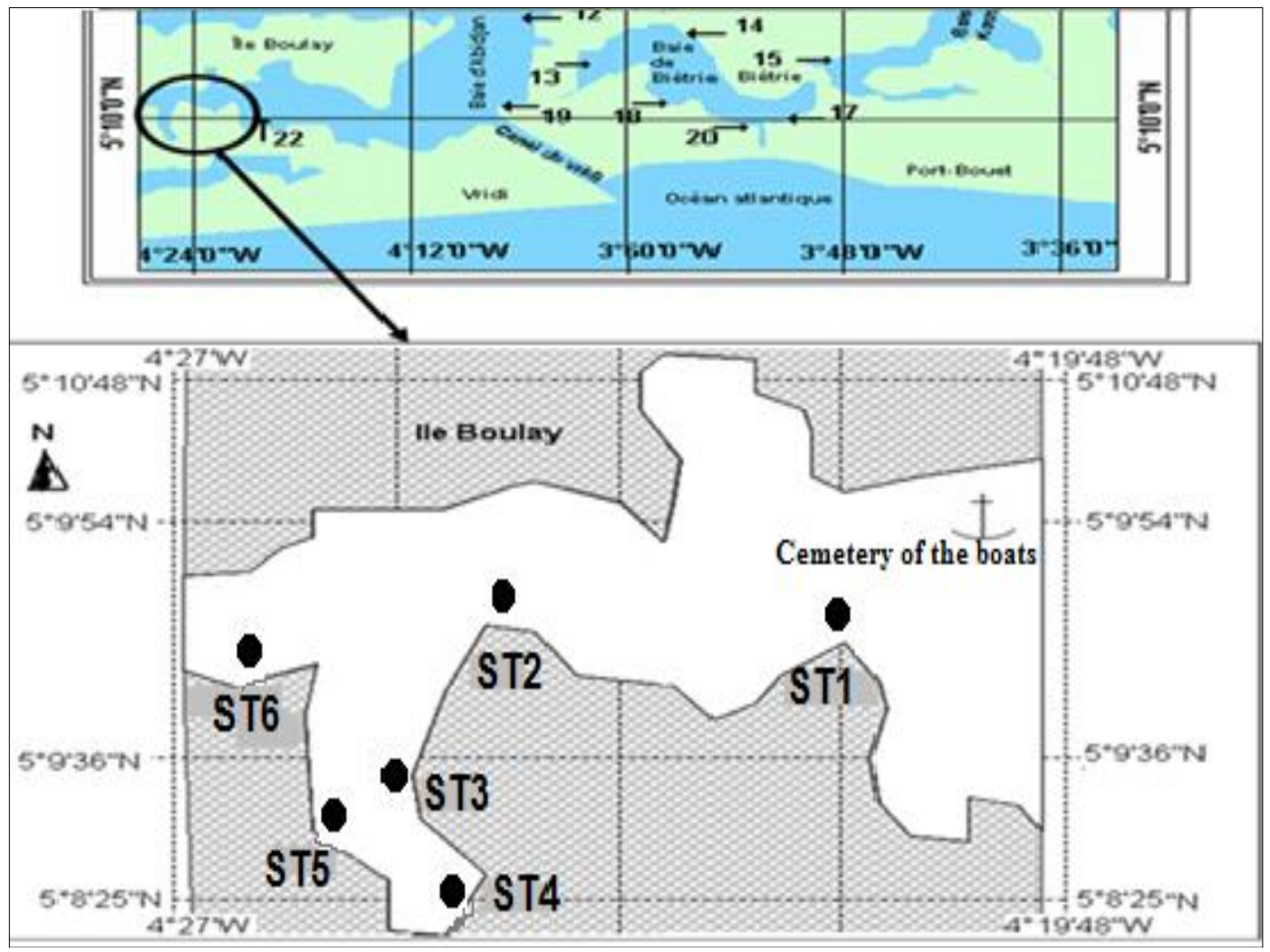

Fig 1: Map showing the Milliardaires Bay and sampling stations $(\bullet)$

Collection of samples: For this study, 360 oysters were randomly collected from about $10 \mathrm{~m}^{2}$ and were found in a size range 4-12 cm shell length in Milliardaires Bay from February 2008 to December 2009, from six selected stations (Fig. 1). All sampling and laboratory equipment were previously washed with detergent, rinsed with distilled water, soaked in 5\% nitric acid, rinsed with distilled water (and oven-dried if necessary) to ensure any trace of cleaning reagent were removed before the sampling and/or samples preparation and analysis. Finally, they were dried at room temperature $\left(25{ }^{\circ} \mathrm{C}\right.$ ) and store in a clean place. At the laboratory, oysters were washed and rinsed with distilled water to move out all particles (such as organic matters) from sediments accumulated on different shells. Then, oysters were analyzed for metal contents.
Analysis of samples: The whole soft tissues of each oyster was move off it shell and collected into Pyrex beakers, and oven-dried at $105{ }^{\circ} \mathrm{C}$ overnight until constant weight. Each dried sample was then homogenized using pestle and mortar and the homogenized powder was stored in polyethylene bag. Two replicates of approximately $0.3 \mathrm{~g}$ of each homogenized powder were weighed into boiling tubes and $10 \mathrm{~mL}$ of concentrated analytical grade nitric acid was added to each sample and left to pre-digest overnight at room temperature in a fume hood. Reagent blanks were processed simultaneously. Then, the boiling tubes were placed on a heating block to reflux at $130{ }^{\circ} \mathrm{C}$ for 6 hours. After cooling, the digests were diluted with $5 \mathrm{~mL}$ of deionized water into $25 \mathrm{~mL}$ volumetric flasks. Each solution was made up to volume with deionized water rinses of the residues. The prepared solutions were 
analyzed for lead, cadmium, nickel, manganese and zinc, by flame atomic absorption spectroscopy (A Perkin, model 3030), with deuterium continuum background correction. The results of samples analyses were submitted to statistical analyses.

Statistical analysis: Microsoft Excel 2007 was used to calculate the mean seasonal concentrations and to draw graphs, while the correlation matrix and the two-way ANOVA analysis were performed with STATISTICA Software (2005, 7.1 Version). Data collected were subjected to the two-way ANOVA analysis of variance to assess whether metal contents in samples varied significantly between locations and seasons, possibilities less than 0.05 $(p<0.05)$ were be considered statistically significant.

\section{Results}

Table 1 presents the results of trace metal concentrations (in $\mu \mathrm{g} / \mathrm{g}$ dry weight) observed in the tissues of oyster Crassostrea gasar collected in Milliardaires Bay in the different seasons and some permissible limits recommended for sea food. The spatial and seasonal of metal concentrations are shown in Fig. 2. The results relative of the two-way ANOVA analysis of variance regarding trace metals in the tissues of $C$. gasar and the results of Pearson correlation analysis are respectively presented in tables 2 and 3. Means and standard deviations of seasonal concentrations of $\mathrm{Pb}, \mathrm{Cd} ; \mathrm{Ni}, \mathrm{Mn}$ and $\mathrm{Zn}$ were found in respective ranges of $40.06 \pm 124.77$ to $301.91 \pm 216.27$, $1.44 \pm 0.87$ to $2.29 \pm 1.64,23.86 \pm 18.42$ to $172.32 \pm 518.55$, $25.96 \pm 19.41$ to $55.00 \pm 63.20$ and $2537.34 \pm 1537.78$ to $3322.99 \pm 2096.71 \mu \mathrm{g} / \mathrm{g}$ dry weight (Table 1). The metal accumulation in the tissues of oyster $C$. gasar were in the decreasing order of $\mathrm{Zn}>\mathrm{Pb}>\mathrm{Ni}>\mathrm{Mn}>\mathrm{Cd}$.

Table 1: Averages and standard deviations (in $\mu \mathrm{g} / \mathrm{g}$ dry weight) of trace metal observed in Crassostrea gasar collected from Milliardaires Bay in different stations.

\begin{tabular}{|c|c|c|c|c|c|}
\hline \multirow{2}{*}{ Seasons } & \multicolumn{4}{|c|}{ Concentration of trace metal in oyster $\boldsymbol{C}$. gasar $(\boldsymbol{\mu g} / \mathbf{g}$ dry weight) } \\
\cline { 2 - 6 } & $\mathbf{P b}$ & $\mathbf{C d}$ & $\mathbf{N i}$ & $\mathbf{M n}$ & $\mathbf{Z n}$ \\
\hline Dry season & $289.55 \pm 181.49$ & $2.17 \pm 0.96$ & $23.86 \pm 18.42$ & $25.96 \pm 19.41$ & $3322.99 \pm 2096.71$ \\
\hline Rainy season & $301.91 \pm 216.27$ & $1.44 \pm 0.87$ & $32.13 \pm 37.64$ & $33.19 \pm 23.45$ & $2537.34 \pm 1537.78$ \\
\hline Flood season & $40.06 \pm 124.77$ & $2.29 \pm 1.64$ & $172.32 \pm 518.55$ & $55.00 \pm 63.20$ & $3188.35 \pm 1587.45$ \\
\hline P.L.(wet weight) & $1^{[21]}$ & $0.5^{[8]}$ & $80^{[8]}$ & N.A & $718^{[5]}$ \\
\hline
\end{tabular}

P.L.: Permissible Limits in wet weight for sea food, N.A.: Not available

SSSA (1993) ${ }^{[21]}$; ISCC (2007) ${ }^{[8]}$; FDA (1993) ${ }^{[5]}$

Regarding individual stations, seasonal concentrations of $\mathrm{Pb}$ ranged from 6.6 to $958.8 \mu \mathrm{g} / \mathrm{g}$ (Fig. $2 \mathrm{a}$ ). In the dry season, the lowest mean concentration $(312.3 \mu \mathrm{g} / \mathrm{g})$ recorded in oysters collected in station ST4, while the highest $(419.0 \mu \mathrm{g} / \mathrm{g})$ was observed in ST2. For the rainy season, the lowest and highest contents were respectively observed in ST3 $(90.91 \mu \mathrm{g} / \mathrm{g})$ and ST6 $(184.87 \mu \mathrm{g} / \mathrm{g})$. In the dry season, station ST4 recorded the lowest mean concentration of $\mathrm{Pb}(6.6 \mu \mathrm{g} / \mathrm{g})$ while ST2 exhibited the highest one with a value of $958.8 \mu \mathrm{g} / \mathrm{g}$. Apart from $\mathrm{ST} 2, \mathrm{~Pb}$ levels were found in the following seasonal ascending rank: dry season $>$ rainy season $>$ flood season (Fig. 2a). The two-way ANOVA analysis of variance showed statistically significant differences $(\mathrm{p} \leq 0.0001)$ between the sampling stations in one hand and, on the over hand, between the three seasons (Table 2). Pb contents observed in $C$ gasar were significantly correlated to the shell lengths $(r=0.99)$ and wet weights $(\mathrm{r}=1.00)$ (Table 3$)$. Fig. $2 \mathrm{~b}$ presents the seasonal variations of $\mathrm{Cd}$ in the different locations. In the dry season, While Cd wasn't detected in samples collected in stations ST3, ST4 and ST6 because of values very below the detection limit of the technique used, respective values of $0.6,0.75$ and $0.91 \mu \mathrm{g} / \mathrm{g}$ were observed in stations ST1, ST2 and ST5. For the rainy season, $\mathrm{Cd}$ concentrations ranged from 0.58 (ST4) to $2.41 \mu \mathrm{g} / \mathrm{g}$ (ST3). The lowest and highest mean concentrations of Cd were respectively observed in ST2 $(1.4 \mu \mathrm{g} / \mathrm{g})$ and ST6 $(3.06 \mu \mathrm{g} / \mathrm{g})$ in the flood season (Fig. 2b). Apart from ST3 for which $\mathrm{Cd}$ level observed in the rainy season was found higher than the flood one, the seasonal rank of $\mathrm{Cd}$ was the opposite of the $\mathrm{Pb}$ one as follows: dry season< $<$ rainy season $<$ flood season (Fig. 2b).

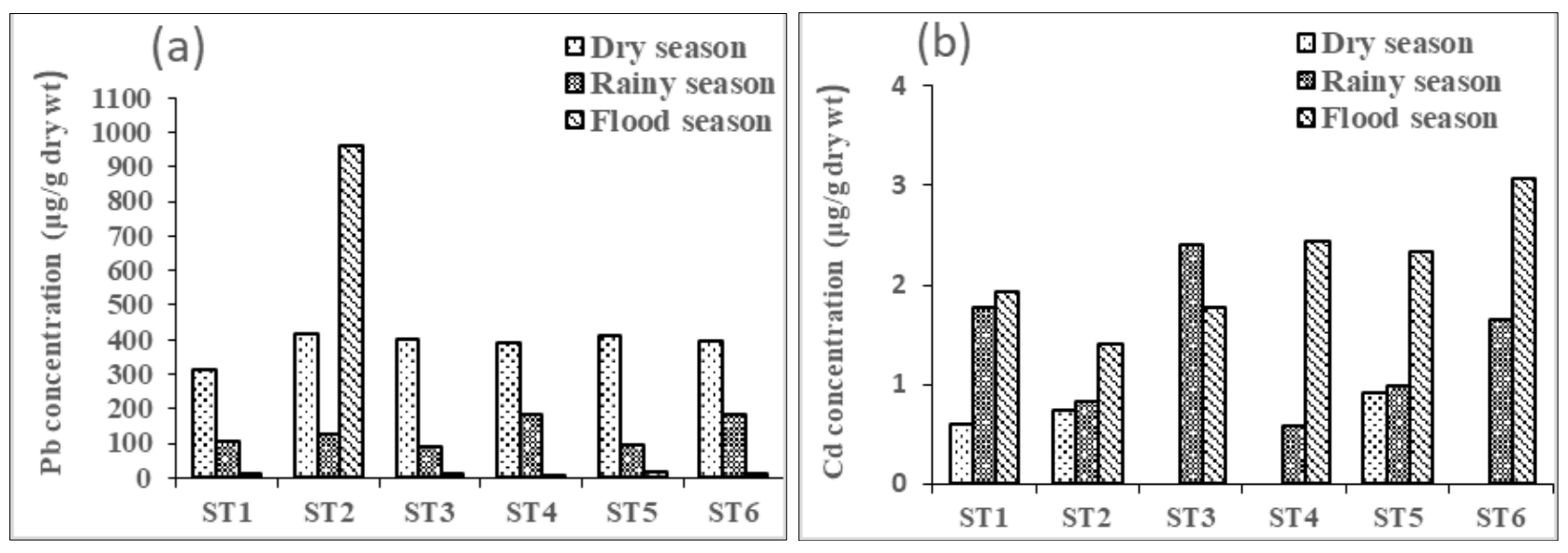



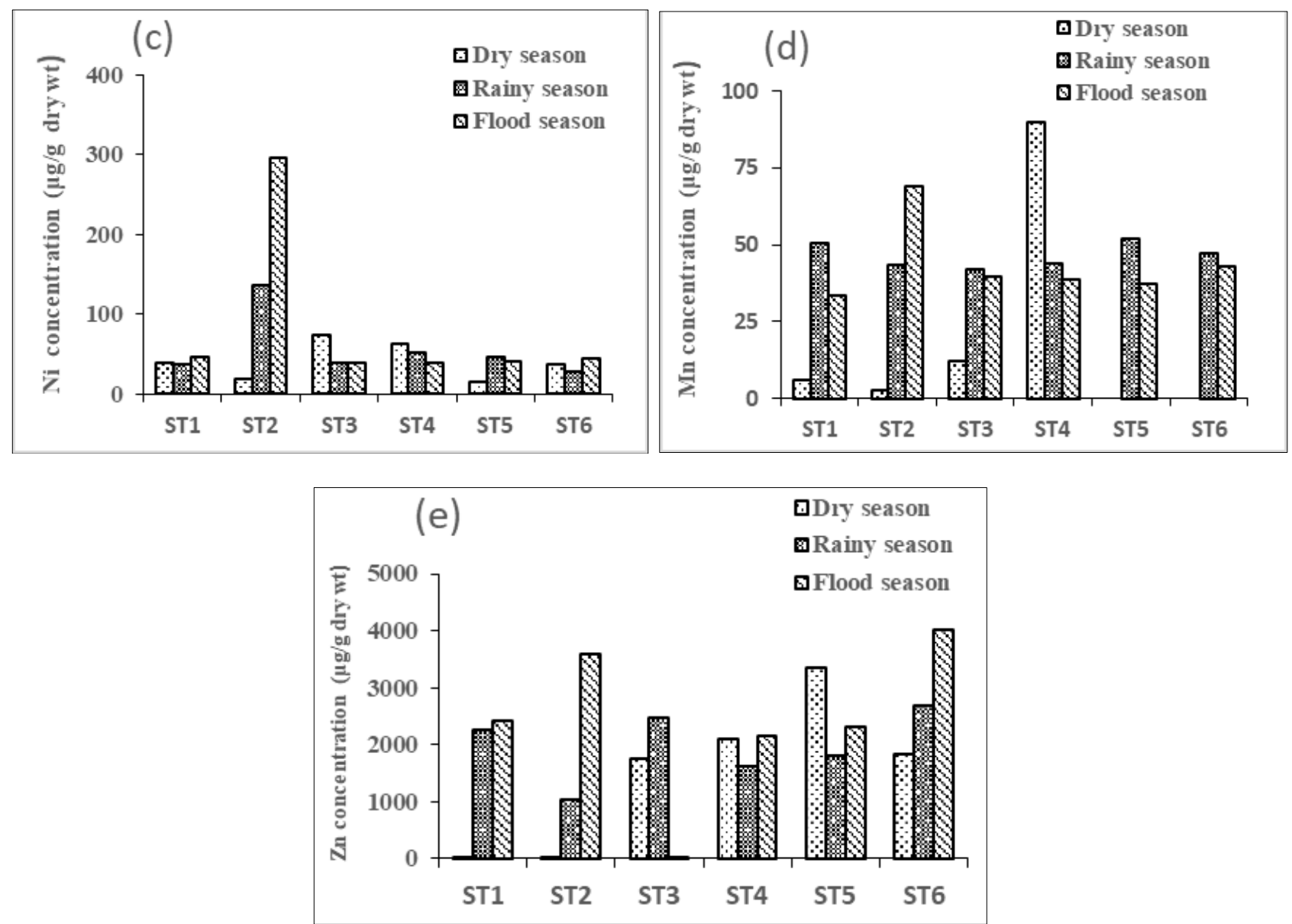

Fig 2: Seasonal variations of lead (a), cadmium (b), nickel (c), manganese (d) and zinc (e) in the soft tissues of Crassostrea gasar from selected stations in Milliardaires Bay.

Cd exhibited statistically significant differences $(p<0.0001)$ between the locations (Table 2). For the seasonal variation in Cd contents, according to the result $(\mathrm{p}=0.9977>0.05)$ of the two-way ANOVA analysis, no significant difference was observed between the three seasons. Cd exhibited positive and statistically significant correlation between $\mathrm{Cd}$ contents in $C$. gasar with the shell lengths $(\mathrm{r}=1.00)$ and the wet weights $(r=0.99)$ of the organisms (Table 3). Statistically significant positive correlation was observed between $\mathrm{Cd}$ contents and those of Mn ( $\mathrm{r}=0.69)$, while a statistically significant inverse correlation $(\mathrm{r}=-0.77)$ was observed between $\mathrm{Cd}$ and $\mathrm{Zn}$ contents in the oysters (Table 3 ). The seasonal contents of $\mathrm{Ni}$ in C. gasar ranged from 14.03 to $136.39 \mu \mathrm{g} / \mathrm{g}$ (Fig. 2c). Regarding spatial trends, Ni contents observed in the oysters were in the following ranges of 14.03-62.7, 27.2-136.39 and $38.8-296.0 \mu \mathrm{g} / \mathrm{g}$, respectively in the dry, rainy and flood seasons (Fig. 2c). Ni exhibited the general following seasonal rank: Flood season $>$ Rainy season $>$ Dry season. Two-way ANOVA analysis of variance showed statistically significant differences between locations $(p<0.0001)$ and seasons $(\mathrm{p}=0.0002)$ (Table 2). Significant correlation was observed between Ni levels $(r=0.69)$ and those of $\mathrm{Mn}$ in the tissues of C. gasar.

Table 2: Results of the two-way ANOVA analysis of variance in trace metals contents.

\begin{tabular}{|c|c|c|c|c|c|c|c|c||c|c|}
\hline \multirow{2}{*}{ Trace metals } & \multicolumn{2}{|c|}{ Pb } & \multicolumn{2}{c|}{ Cd } & \multicolumn{2}{c||}{ Ni } & \multicolumn{2}{c|}{ Mn } & \multicolumn{2}{c|}{ Zn } \\
\cline { 2 - 11 } & F-ratio & p-value & F-ratio & p-value & F-ratio & p-value & F-ratio & p-value & F-ratio & p-value \\
\hline Locations & 16880 & 0.0000 & 921 & 0.0000 & 16474 & 0.0000 & 748 & 0.0000 & 1291935 & 0.0000 \\
\hline Seasons & 18. & 0.0001 & 1 & 0.9977 & 18 & 0.0002 & 1 & 0.7780 & 1405 & 0.0000 \\
\hline
\end{tabular}

Table 3: Correlation matrix of metal concentrations and biotic parameters (shell length and wet weight) of oyster C. gasar in Milliardaires Bay.

\begin{tabular}{|c|c|c|c|c|c|c|c|}
\hline & Shell length & Wet weight & Pb & Cd & Ni & Mn & Zn \\
\hline Shell length & 1.00 & & & & & & \\
\hline Wet weight & $0.99^{*}$ & 1.00 & & & & & \\
\hline $\mathrm{Pb}$ & -0.26 & -0.17 & 1.00 & & & & \\
\hline $\mathrm{Cd}$ & $1.00^{*}$ & $0.98^{*}$ & -0.28 & 1.00 & & & \\
\hline $\mathrm{Ni}$ & 0.04 & -0.02 & -0.31 & 0.05 & 1.00 & & \\
\hline $\mathrm{Mn}$ & $0.68^{*}$ & $0.64^{*}$ & -0.43 & $0.69^{*}$ & $0.68^{*}$ & 1.00 & \\
\hline $\mathrm{Zn}$ & $-0.77^{*}$ & $-0.79^{*}$ & 0.20 & $-0.77^{*}$ & -0.08 & -0.46 & 1.00 \\
\hline
\end{tabular}

*: Significant correlation at $p<0.05$. 
Regarding the selected stations, seasonal mean values of Mn in oysters ranged from 2.83 to $89.93 \mu \mathrm{g} / \mathrm{g}$. The same range was observed in the dry season (Fig. 2d). For the dry season, Mn was not detected in samples collected in stations ST5 and ST6 (Fig. 2d). Respective concentrations ranges of 42.12 to $51.74 \mu \mathrm{g} / \mathrm{g}$ and 33.54 to $69.06 \mu \mathrm{g} / \mathrm{g}$ were observed in the rainy and flood seasons. For present study, Mn concentrations were in the following decreasing seasonal rank: Flood season $>$ Rainy season $>$ Dry season (Fig. 2d). While sampling locations of oysters were found significantly different $(p<0.0001)$, no significant differences was observed between the studied seasons $(\mathrm{p}=0.7780)$ (Table 2$)$. Significant positive correlations were observed between Mn levels and the shell lengths $(r=0.68)$ and the wet weights $(r=0.64)$ of the animals (Table 3). Significant positive correlations were also observed between $\mathrm{Mn}$ and $\mathrm{Cd}(\mathrm{r}=0.69)$ and also between the concentrations of Mn and those of Ni (r=0.68) (Table 3). Fig. 2e presents the seasonal trends of $\mathrm{Zn}$ contents in $C$. gasar. Seasonal mean concentrations of $\mathrm{Zn}$ ranged from 17.6 to 4017 $\mu \mathrm{g} / \mathrm{g}$. Respective ranges of 17.6-3358; 1047.49-2693.78 and $37.46-4017 \mu \mathrm{g} / \mathrm{g}$ were observed in the dry, rainy and flood seasons for $\mathrm{Zn}$ contents (Fig. 2e). Zn exhibited the following seasonal descending rank: Rainy season $<$ Flood season $<$ Dry season (Fig. 2e). Statistically significant inverse correlations were observed between $\mathrm{Zn}$ and shell lengths ( $\mathrm{r}=-0.77)$ and wet weights $(\mathrm{r}=-0.79)$ (Table 3). Significant inverse correlations $\mathrm{Zn} / \mathrm{Cd}(\mathrm{r}=-0.77)$ and $\mathrm{Zn} / \mathrm{Mn}(\mathrm{r}=-0.46)$ were also observed (Table 3).

\section{Discussion}

$\mathrm{Pb}$ exhibited concentrations in all the three seasons higher than the recommended values for FAO/WHO (1992) ${ }^{[4]}$ as $0.05 \mu \mathrm{g} / \mathrm{g}$, US-FDA (2003) ${ }^{[26]}$ as $1.7 \mu \mathrm{g} / \mathrm{g}$, SSSA (1993) ${ }^{[21]}$ as $1.0 \mu \mathrm{g} /$. Apart from $\mathrm{Cd}$ which exhibited contents higher the recommended limit in the flood season (ISCC, 2007) in oysters collected in station ST6 which recorded a level of 3.06 $\mu \mathrm{g} / \mathrm{g}$, levels observed for $\mathrm{Ni}, \mathrm{Mn}$ and $\mathrm{Zn}$ were lower or within the permissible limits for sea food (Table 1, (Fig. 2). Pb contents observed in C. gasar inhabiting the Milliardaires Bay were higher than the levels $(0.004-0.02 \mathrm{mg} / \mathrm{g} \mathrm{d} . \mathrm{w})$ reported by Onwuteaka et al. (2015) ${ }^{[14]}$ for the same organism from water creek of the NIGER Delta (Nigeria). Excessive concentrations of toxic metals like $\mathrm{Pb}$ and $\mathrm{Cd}$ in the tissues and organs of marine organisms may adversely affect cellular functions by interacting with systemic enzymes and can also lead to dysfunction of the endocrine system, immune system, metabolism, reproduction and growth (Hylland, 2006) ${ }^{[7]}$. Considering high concentrations of $\mathrm{Pb}$ observed in the present work, oysters inhabiting the Milliardaires Bay were found unsafe for human consumption (Table 1). Cd levels observed in the present study were generally lower than the permissible limit of $0.5 \mu \mathrm{g} / \mathrm{g}$ wet weight (ISCC (2007) ${ }^{[8]}$ and those (0.001-0.05 mg/g) found in C. gasar from water creek of the NIGER Delta (Nigeria) (Onwuteaka et al., 2015) [14]. According to our data, in oyster C. gasar, a small part of $\mathrm{Zn}$ can be substituted by the $\mathrm{Cd}$, a toxic metal even at low levels (Table 3). Levels of $\mathrm{Ni}$ observed in C. gasar from Milliardaires Bay were lower than the permissible limit (FDA, 1993) ${ }^{[5]}$, and higher than those found in C. gasar from water creek of the NIGER Delta (Nigeria) (Onwuteaka et al., $2015)^{[14]}$. Levels of $\mathrm{Zn}$ observed in the present study were in the same range with those reported by Metongo (1991) ${ }^{[13]}$ for the same oyster $C$. gasar collected in several areas in the Ebrié Lagoon. Zn, as a constituent of haemocyanin in molluscs and its major importance in metabolic processes by ensuring the proper functioning of many enzymes, occur in higher levels in the tissues of bivalves such as oysters (Jakimska et al., 2011) ${ }^{[9]}$. The statistically significant spatial variations in the contents of the five metals $(\mathrm{Pb}, \mathrm{Cd}, \mathrm{Ni}, \mathrm{Mn}$ and $\mathrm{Zn}$ ) are in agreement with the spatial variations in physicochemical parameters, nutrients, metals and/ or organic matter observed in waters and/or sediments collected in the same Milliardaires Bay (Tuo et al., 2012; Tuo et al., 2013; Bakary et al., 2014; Tuo et al., 2015) ${ }^{[22,23,2,24]}$. Bakary et al. (2015) ${ }^{[3]}$ did not observed significant difference in metals accumulation in $A$. senilis living in the same area, indicating a difference in metal accumulation for the two bivalve's species. The differences between the studied seasons were statistically significant $(p<0.001)$ for $\mathrm{Pb}, \mathrm{Ni}$ and $\mathrm{Zn}$, at the opposite of $\mathrm{Cd}$ and $\mathrm{Mn}$ with no significant differences between seasons regarding metal concentrations (Table 2). In the same Milliardaires Bay, Bakary et al. (2015) ${ }^{[3]}$ have reported significant seasonal variations in total concentrations of $\mathrm{Zn}, \mathrm{Cu}, \mathrm{Cd}$ and $\mathrm{Pb}$ in $A$. senilis between the dry and rainy seasons. Indeed, trace metals bioaccumulation in marine animals including oysters depend on their levels in the surrounding waters and sediments that are also their feeding sources. The uptake, fate, effects of contaminants, gender, age, body size, nutrition, reproductive status, environmental factors ( $\mathrm{pH}$, temperature, salinity, dissolved oxygen, etc.), metal bioavailability, etc. are among factors that can influence the bioaccumulation of pollutants like metals in marine organisms (Zhou et al., 2008) ${ }^{[30]}$. Statistically significant positive correlations observed between the $\mathrm{Cd}$ (and $\mathrm{Mn}$ ) with shell lengths and wet weights indicated an increase in selected metals contents in the tissues of the organisms along their life. At the opposite of $\mathrm{Cd}$ and $\mathrm{Mn}$, statistically significant inverse correlations were observed between $\mathrm{Zn}$ contents and shell lengths, wet weights and $\mathrm{Cd}$ contents, due to the fact that $\mathrm{Zn}$ is an essential metal for oysters on one hand, and on the over hand in relation with a possible competition between $\mathrm{Zn}$ and Cd. A moderate inverse correlation was also observed between $\mathrm{Mn}$ and $\mathrm{Pb}(\mathrm{Mn} / \mathrm{Pb}, \mathrm{r}=-0.43)$, as a result of a competition between the two metals. Positive relationship were observed between $\mathrm{Mn}, \mathrm{Cd}$ and $\mathrm{Ni}$ as the result of interactions among these metals within the oysters, in terms of competition for binding locations on specific enzymes or receptors during the processes of absorption, excretion, sequestration, or as a target site. Páez-Osuna and Mamolejo, $(1990)^{[17]}$ have also reported positive correlation between $\mathrm{Pb}$, $\mathrm{Cd}, \mathrm{Ni}$ and $\mathrm{Co}$ in Crassoarea corteziensis and in ambient marine system. The substitution of essential metals (Mn and $\mathrm{Zn})$ with non-essential ones $(\mathrm{Cd}$ and $\mathrm{Pb})$ can lead to an increase of hazardous effects on oysters and, finally on humans.

\section{Conclusion}

Seasonal variations of the studied trace metals in oyster Crassostrea gasar were found significant for $\mathrm{Pb}, \mathrm{Ni}$, and $\mathrm{Zn}$, except for $\mathrm{Cd}$ and $\mathrm{Mn}$ which also recorded highest concentrations in the flood and rainy seasons. $\mathrm{Pb}$ concentrations observed in the dry season were higher than those of the wet (flood and rainy) ones in all the sampling stations. For $\mathrm{Ni}$ and $\mathrm{Zn}$, the seasonal variations were very dependent on the location of the selected sampling stations. $\mathrm{Pb}$ levels were higher than the permissible limit, indicating that oysters from Milliardaires Bay were unsafe for human consumption. However, $\mathrm{Pb}$ levels observed in the flood season were seven times lower than those of the other seasons. Overall, the present study provided baseline 
information on the seasonal variations of the concentrations of $\mathrm{Pb}, \mathrm{Cd}, \mathrm{Ni}, \mathrm{Mn}$ and $\mathrm{Zn}$ in $C$. gasar inhabiting the Milliardaires Bay which may be needed for further studies. In addition, anthropogenic activities have to be reduced around the Milliardaires Bay to avoid its contamination in pollutants such as trace metals, for the protection of the biodiversity.

\section{Acknowledgments}

The authors gratefully acknowledge the support and facilities of the Oceanologic Research Center (Centre de Recherches Océanologiques d'Abidjan) of Côte d'Ivoire which supported the Institutional Project.

\section{References}

1. Arifin Z, Bendell-Young LI. Feeding response and carbon assimilation by the blue mussel Mytilus trossulus exposed to environmentally relevant seston matrices. Marine Ecology Progress Series. 1997; 160:241-253.

2. Bakary I, Marcellin YK, Olivier EA, Bernard SM, Albert T, Yobou B. Heavy metals pollution in bottom surface sediments, and metal fluxes through the sediment/ water interface, Milliardaires bay, Ebrie lagoon (Côte d'Ivoire). Acad. J Environ. Sci. 2014; 2(5):063-073. DOI: http://dx.doi.org/10.15413/ajes.2013.0036.

3. Bakary I, Yao KM, Etchian OA, Soro MB, Trokorey A, Bokra Y. Zinc, copper, cadmium, and lead concentrations in water, sediment, and Anadara senilis in a tropical estuary. Environ. Monit. Assess. 2015; 187:762. DOI: 10.1007/s10661-015-4976-6.

4. FAO/WHO. Food Sandard Programme. 2nd Edn., Codex Alimentarius Commission, Geneva, 1992, 1.

5. FDA. Guidance document for lead in shellfish. Center for Food Safety and Applied Nutrition. United States Food and Drug Administration, Washington, D.C., 1993.

6. Góngora-Gómez AM, García-Ulloa M, Muñoz-Sevilla NP, Domínguez-Orozco AL, Villanueva-Fonseca BP, Hernández-Sepúlveda JA et al. Heavy-metal contents in oysters (Crassostrea gigas) cultivated on the southeastern coast of the Gulf of California, Mexico. Hidrobiológica. 2017; 27(2):219-227.

7. Hylland K. Biological effects in the management of chemicals in the marine environment, Mar. Pollut. Bull. 2006; 53:614.

8. ISCC. National shellfish sanitation program. Guide for the control of molluscan shellfish. Interstate Shellfish Sanitation Conference. U.S. Food and Drug Administration, Department of Health and Human Services. Washington DC, 2007, 549p.

9. Jakimska A, Konieczka P, Skóra K, Namieśnik J. Bioaccumulation of metals in tissues of marine animals. Part II - metal concentrations in animal tissues, Pol. J Environ. Stud. 2011; 20(5):1127-1146.

10. Kanthai LD, Gobin JF, Beckles DM, Lauckner B, Mohammed A. Metals in sediments and mangrove oysters (Crassostrea rhizophorae) from the Caroni Swamp, Trinidad. Environmental Monitoring and Assessment. 2014; 186:1961-1976. DOI: 10.1007/s10661-0133510-y.

11. Kouakou KF, Aman JB, Diaha NC, Otchoumou A. Histological study of the sexual cycle of the oyster Crassostrea gasar of the Ebrié lagoon of Côte d'Ivoire. Journal of Chemical, Biological and Physical Sciences. 2018; 8(1):180-189. DOI: 10.24214/jcbps.B.8.1.18089.

12. Lopez-Artiguez M, Soria ML, Repetto M. Heavy metal in bivalve molluscs in the Huelva Estuary. Bull. Environ.
Contam. Toxicol. 1989; 42 :634-42.

13. Metongo BS. Concentrations en métaux toxiques chez Crassostrea gasar (Huître de mangrove en zone urbaine lagunaire d'Abidjan (Côte d'Ivoire). J. Ivoir. Océanol. Limnol. Abidjan, 1991; 1(1). Janvier, 1991, 33-45.

14. Onwuteaka JN, Edoghotu AJ, Friday U, Wokoma AOF, Bob-Manuel FG. Heavy metals contamination of the sessile bivalve, Crassostrea gasar (mangrove oyster) in Ai post oil spilled brackish water creek of the NIGER Delta, Nigeria, Annals of Biological Research. 2015; 6(11):72-77.

15. Ouro-Sama K, Solitoke HD, Gnandi K, Afiademanyo KM, Bowessidjaou EJ. Évaluation et risques sanitaires de la bioaccumulation de métaux lourds chez des espèces halieutiques du système lagunaire togolais. [VertigO] La revue électronique en sciences de l'environnement. 2014; 14(2). URL: http://vertigo.revues.org/15093; DOI:10.4000/ vertigo.15093.

16. Páez-Osuna F, Frías-Espericueta MG, Osuna-López JL. Trace metal concentration in relation to season and gonadal maturation in the oyster Crassostrea iridescens. Marine Environmental Research. 1995; 40:19-31. DOI: 10.1016/0141-1136(94)00004-9.

17. Páez-Osuna F, Mamolejo Rivas C. Trace metals in tropical coastal lagoon bivalves, Crussostrea corteziensis. Bull. Environ. Contam. Toxicol. 1990; 45:538-44.

18. Páez-Osuna F, Osuna-Martínez CC. Bioavailability of cadmium, copper, mercury, lead, and zinc in subtropical coastal lagoons from the Southeast Gulf of California using mangrove oysters (Crassostrea corteziensis and Crassostrea palmula). Archives of Environmental Contamination and Toxicology. 2015; 68:305-316. DOI: 10.1007/ s00244-014-0118-3.

19. Phillips DJH, Muttarasin K. Trace metals in bivalve molluscs from Thailand. Mar. Environ. Res. 1985; 15:215-34

20. Prabal B, Abhijit M, Kakoli B, Shah NC. Seasonal variation of Metals Accumulation in Water and Oyster (Saccostrea cucullata) inhabiting central and western sector of Indian Sundarbans. Environmental Research Journal. 2011; 5(3):121-130.

21. SSSA. Norma Official Mexicana NOM-031-SSA1-1993. Bienes y servicios. Productos de la pesca. Molluscos bivalvos frescos-refrigerados y congelados. Especificaciones sanitarias. Secretariat de Salud. Diario oficial de la Federación, 6 de marzo de, 1995.

22. Tuo AD, Soro MB, Trokourey A, Bokra Y. Assessment of waters contamination by nutrients and heavy metals in the Ebrié Lagoon (Abidjan, Ivory Coast). Res. J Environ. Toxicol. 2012; 6:198-209.

23. Tuo AD, Yeo KM, Soro MB, Trokourey A, Bokra Y. Contamination of surface sediments by heavy metals in Ebrié Lagoon (Abidjan, Ivory Coast). Int. J Chem. Technol. 2013; 5:10-21. DOI: 10.3923/ijct.2013.10.21.

24. Tuo AD, Soro MB, Trokourey A, Bokra Y. Evidence of organic pollution observed in Ebrié Lagoon around Abidjan City (Côte d'Ivoire). Am. Int. J Res. Formal Appl. Nat. Sci., 2015; 11: 40-45.

25. Tuo AD, Soro MB, Trokourey A, Bokra Y. Bioaccumulation of Trace Metals in Oyster (Crassostrea gasar) from the Milliardaires Bay (Ebrié Lagoon, Côte d'Ivoire). J Chem. Bio. Phy. Sci. Sec. B. 2019-2020; 10(1):012-020. DOI:10.24214/jcbps.B.10.1.01220.

26. US-FDA. Guide for the control of Molluscan Shellfish Public Health Service, Food and Drug Administration, 
USA. 2003, 120.

27. Weng N, Wang W-X. Seasonal fluctuations of metal bioaccumulation and reproductive health of local oyster populations in large contaminated estuary, Environmental Pollution. 2009; 250:175-185.

28. Yapi JN, Blé MC, Etchian AO, Kadjo V, Yao K. Population dynamics of mangrove oyster, Crassostrea gasar of the lagoons Ebrié and Aby, Côte d'Ivoire. International Journal of Sciences: Basic and Applied Research (IJSBAR). 2017; 36(8):122-137.

29. Yapi JN, Blé MC, Etchian AO, Kadjo V, Yao K. Comparative study of reproduction cycle of mangrove oyster (Crassostrea gasar) of the lagoons Ebrié and Aby, Côte d'Ivoire. J Bio. Envi. Sci. 2018; 12(1):40-51.

30. Zhou Q, Zhang J, Fu J, Shi J, Jiang G. Biomonitoring: An appealing tool for assessment of metal pollution in the aquatic ecosystem. Analytica Chimica Acta. 2008; 606:135-150. Doi.10.1016/j.aca.2007.11.018. 